\title{
Pathophysiology of type 2 diabetes melli- tus in youth: the evolving chameleon
}

\author{
Fisiopatologia do diabetes melito tipo 2 no jovem: um camaleão em evolução
}

Hala Tfayli ${ }^{1,2}$, Silva Arslanian ${ }^{1,2}$

\begin{abstract}
Type 2 diabetes mellitus (T2DM) in children and adolescents is an important Public Health problem against the backdrop of the epidemic of childhood obesity. The clinical presentation ofT2DM in youth is heterogeneous from minimal symptomatology to diabetic ketoacidosis. The increasing rates of youth T2DM have paralleled the escalating rates of obesity, which is the major risk factor impacting insulin sensitivity. Additional risk factors include minority race, family history of diabetes mellitus, maternal diabetes during pregnancy, pubertal age group and conditions associated with insulin resistance (IR) - such as polycystic ovary syndrome (PCOS). The pathophysiology of T2DM has been studied extensively in adults, and it is widely accepted that IR together with beta-cell failure are necessary for the development of clinical diabetes mellitus in adulthood. However, pathophysiologic studies in youth are limited and in some cases conflicting. Similar to adults, IR is a prerequisite, but beta-cell failure is necessary for progression from normal glucose tolerance to prediabetes and frank diabetes in youth. Even though rates of T2DM in youth are increasing, the overall prevalence remains low if compared with type 1 diabetes mellitus (T1DM). However, as youth with T1DM are becoming obese, the clinical distinction between T2DM and obese T1DM has become difficult, because of the overlapping clinical picture with evidence of islet cell autoimmunity in a significant proportion of clinically diagnosed youth with T2DM. The latter are most likely obese children with autoimmune T1DM who carry a misdiagnosis of T2DM. Further research is needed to probe the pathophysiological, immunological, and metabolic differences between these two groups in the hopes of assigning appropriate therapeutic regimens. These challenges combined with the evolving picture of youth T2DM and its future complications provide unending opportunities for acquisition of new knowledge in the field of childhood diabetes. Arq Bras Endocrinol Metab. 2009;53(2):165-174.
\end{abstract}

Keywords

Policystic ovarian syndrome; obesity; diabetic physiopathology

\section{RESUMO}

Em um cenário de uma epidemia de obesidade, o diabetes melito tipo 2 (DM2) em crianças e adolescentes é um importante problema de Saúde Pública. As manifestações clínicas do DM2 na juventude são heterogêneas e vão desde sintomas leves até a cetoacidose diabética. As taxas crescentes de DM2 no jovem seguem em paralelo ao aumento da obesidade, a qual constitui o mais importante fator de risco para a redução da sensibilidade à insulina. Outras condições de risco para o DM2 são: minorias étnicas, história familiar de DM2, diabetes materno durante a gestação, idade puberal e situações associadas à resistência à insulina (RI) - como a síndrome dos ovários policísticos (SOP). A fisiopatologia do DM2 tem sido muito estudada em adultos, sendo aceita como condições necessárias à RI em conjunto com a disfunção da célula beta. Estudos da fisiopatologia em jovens são escassos e conflitantes. Semelhante ao que se passa com os adultos, a Rl é um pré-requisito, mas a falência da célula beta é necessária para que haja progressão da tolerância normal à glicose para o pré-diabetes e DM2. Mesmo com o aumento da incidência de DM2 no jovem, a prevalência permanece baixa em comparação com o diabetes mellitus tipo 1 (DM1). Se uma criança com DM1 é obesa, a distinção clínica entre o DM2 e DM1 é dificultada, pois existem semelhanças clínicas e evidências da presença de autoimunidade contra a célula beta em uma significativa proporção de jovens diagnosticados com DM2. Esta condição normalmente representa uma criança obesa com autoimunidade para DM1 com o diagnóstico equivocado de DM2. Novas pesquisas são necessárias para caracterizar os diferentes mecanismos fisiopatológicos, imunológicos e metabólicos entre estes dois grupos, na esperança de que sejam alcançados regimes terapêuticos apropriados. Esses desafios e o quadro em mutação do diabetes na criança e no adolescente nos fornecem oportunidades infindáveis para a aquisição de novos conhecimentos no campo da diabetologia. Arq Bras Endocrinol Metab. 2009;53(2):165-174.
Division of Weight Management and Wellness from Center ${ }^{2}$ Division of Pediatric Endocrinology, Metabolism and Diabetes Mellitus, Children's Hospital of Pittsburgh, University of Pittsburgh Medical Center, Pittsburgh, USA

Correspondence to: Silva Arslanian

Children's Hospital of Pittsburgh 3705 Fifth Avenue

Pittsburgh, Pennsylvania 15213,

U.S.A.

silva.arslanian@chp.edu

Received in Feb/28/2009 Accepted in Mar/02/2009 


\section{INTRODUCTION}

$\mathrm{T}$ ype 2 diabetes mellitus (T2DM), classically a diagnosis restricted to adults, became increasingly recognized in children and adolescents worldwide over the last two decades (1-5). In the United States, between 2002 and 2003, the proportion of physician-classified T2DM among newly diagnosed diabetes cases in the 10 to 19 years age group ranged from $14.9 \%$ in non Hispanic whites to $46.1 \%$ in Hispanics, $57.8 \%$ in African Americans and $86.2 \%$ in American Indians (5). The rates are lower in Europe, where T2DM accounts for $1 \%$ to $2 \%$ of young-onset diabetes mellitus cases (6-8); higher in Taiwan, where T2DM accounts for $54.2 \%$ of newly diagnosed diabetes mellitus cases in school age children (9); in Japan, where the incidence of T2DM in school age children is estimated at 3.0/100,000/yr (10); and, among Kuwaiti children, whose reported prevalence is 34.9 per 100,000 (11). The increase in T2DM cases in youth has paralleled the epidemic increase in childhood obesity and an increase in the prevalence of adult $\operatorname{T2DM}(1,12)$. In addition to obesity, which is the major risk factor, genetic and environmental influences as well as family history of diabetes, minority ethnic background, female gender, polycystic ovary syndrome (PCOS), and sedentary lifestyle operate together and enhance the risk of youth T2DM (13). Thus, environmental, behavioral and social factors contribute to unraveling diabetes in the genetically susceptible youth. Important aspects in the pathophysiology of T2DM in children have been elucidated over the last decade; however, research in this area remains in its early stages, with several questions to be explored. In this article, we reviewed the studies pertinent to the pathophysiology of T2DM in children and adolescents.

\section{PATHOPHYSIOLOGY OF T2DM}

Normal glucose homeostasis and glucose disposition index

Under normal physiologic conditions, glucose concentrations remain within a narrow range in the fasting as well as in the fed state. This tight glucose regulation is maintained by a delicate balance between insulin secretion and insulin sensitivity (14). A hyperbolic relationship governs this balance, such as the product of insulin sensitivity and insulin secretion is a constant at a given glucose tolerance in any individual (15). This product, known as the glucose disposition index (GDI), is a more accurate reflection of pancreatic be- ta-cell function than simple quantification of insulin secretion, as it normalizes the beta-cell response to the degree of insulin resistance (IR) (16). In individuals with normal glucose tolerance (NGT), a decrease in insulin sensitivity of the peripheral tissues results in a compensatory increase in insulin secretion, and normoglycemia is maintained. Failure of this compensatory response can lead to glucose intolerance and diabetes $(15,17)$ (Figure 1).

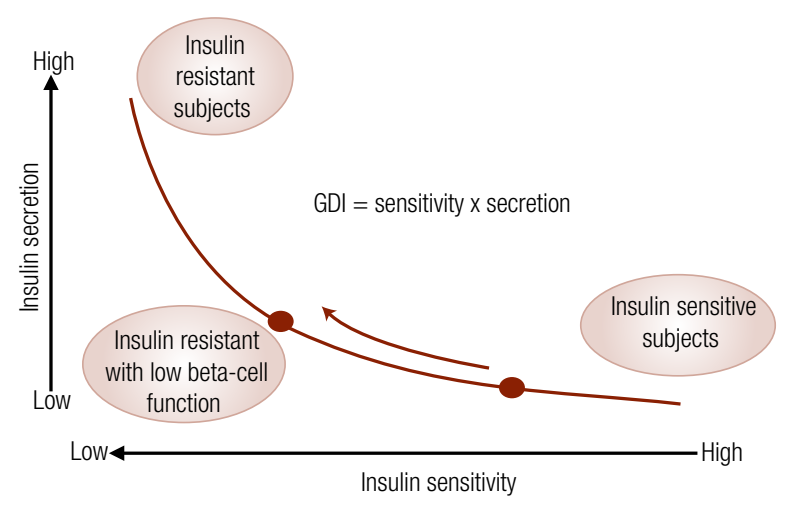

$\mathrm{GDI}=$ glucose disposition index

Figure 1. Hyperbolic relationship between insulin sensitivity and insulin secretion. Adapted with permission from Arslanian (15).

Currently, it is well accepted that adult T2DM is a " 2 hit" disease, in which IR is necessarily accompanied by beta-cell failure $(16,17)$. The sequence of development of these abnormalities, the causes of failure of the pancreatic beta-cell and the nature of the signals from the insulin resistant tissues that fail to induce an appropriate beta-cell response remain the subject of ongoing debate and research in both the adult and the pediatric literature. However, there is a general consensus that IR with compensatory hyperinsulinemia is the earliest abnormality with the subsequent step being impairment in insulin secretion, resulting in hyperglycemia and overt clinical diabetes (18). In the following sections of the present paper, the pediatric studies that assessed insulin sensitivity and beta-cell function in young patients with T2DM are reviewed.

\section{Insulin sensitivity in youth T2DM}

Obesity, particularly abdominal obesity, PCOS, pubertal age group and intrauterine exposure to hyperglycemia are among the risk factors for development of 
T2DM in children and adolescents (18). IR is a common denominator in individuals carrying one or more of these risk factors, and represents a necessary, albeit not sufficient, condition in the progression to clinical diabetes. The few studies that evaluated children with T2DM showed variable results regarding the degree of decline in insulin sensitivity in youth with T2DM compared to obese controls with or without impaired glucose tolerance (19-24). Using the state of the art hyperinsulinemic-euglycemic clamp technique, our group reported significantly lower insulin-stimulated glucose disposal, total, oxidative and non-oxidative in a cohort of 14 obese adolescents with T2DM compared with 20 obese controls with similar degrees of obesity and body fat distribution. Adolescents with T2DM had $\sim 50 \%$ lower in vivo insulin sensitivity when compared with their obese non diabetic peers (Figure 2A) (20).

Similar to our findings, Elder and cols. reported 3 to 4 -fold lower insulin sensitivity in a group of 16 obese adolescents with T2DM compared with 13 obese con- trols with similar percent of body fat mass, using the modified intravenous glucose tolerance test (IVGTT) with minimal model assessment (22). Abdominal fat distribution was not assessed in this study (22).

In a smaller study from France, Druet and cols. reported significant IR in six patients with T2DM, with different ethnicities, using the euglycemic-hyperinsulinemic clamp (23). Contrary to these findings, Kobayashi and cols., using the modified IVGTT with minimal model assessment, found similar insulin sensitivity in 12 obese Japanese adolescents with relatively mild T2DM, 10 obese adolescents with more severe T2DM, and 18 obese adolescents with NGT. The three obese groups, however, had lower insulin sensitivity than 26 lean controls (19).

Similarly, Weiss and cols., using the hyperglycemic clamp technique, reported no difference in insulin sensitivity between 10 obese adolescents with T2DM, 22 equally obese adolescents with impaired glucose tolerance (IGT) and 30 equally obese adolescents with
A

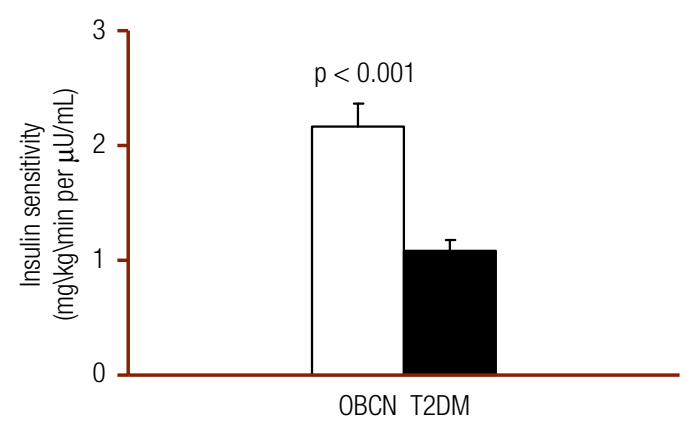

C

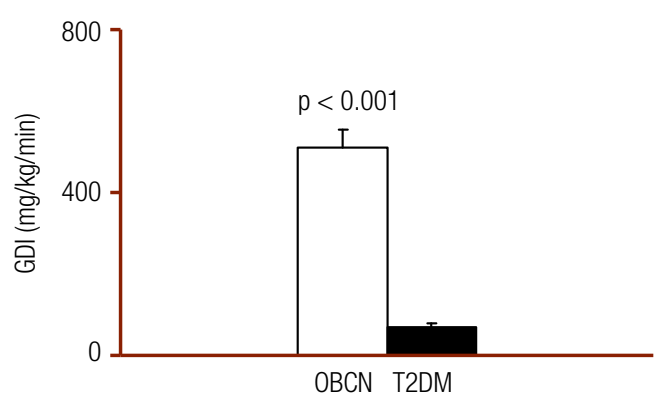

B

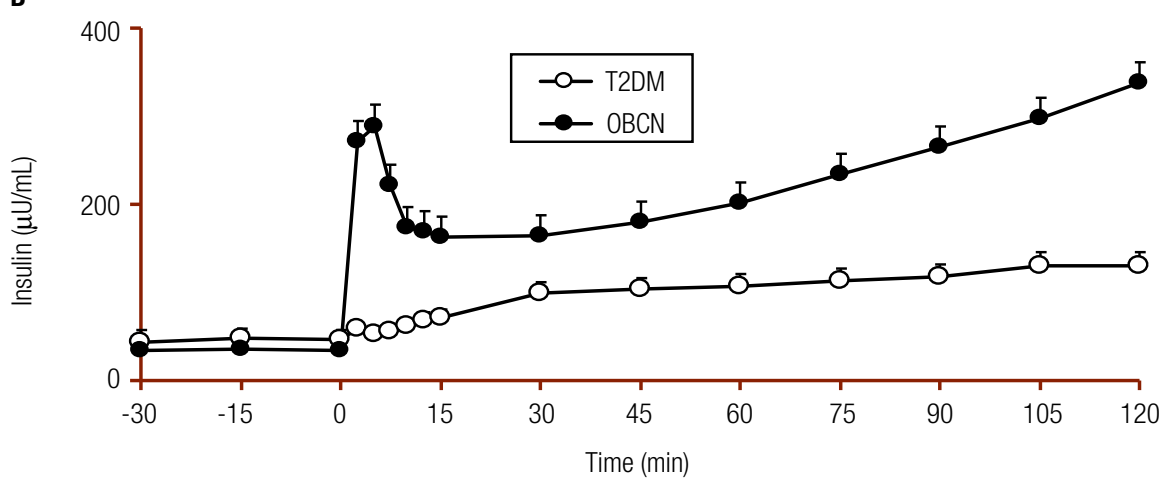

$\mathrm{OBCN}=$ obese children with normal glucose tolerance

Figure 2. (A) Insulin sensitivity; (B) insulin secretion; (C) glucose disposition index in T2DM patients (black bars) and obese controls (white bars). Adapted with permission from Gungor and cols. (20). 
NGT (21). However, the same group had previously reported contrasting findings by showing significantly lower peripheral insulin sensitivity, and lower non-oxidative glucose metabolism in obese adolescents with IGT compared with NGT with similar body mass index (BMI) and percent of body fat, using the hyperinsulinemic-euglycemic clamp (25).

This discrepancy between the various studies is due partly to the methodology used in assessing insulin sensitivity. The hyperinsulinemic-euglycemic clamp used in the latter study by Weiss and cols. (25), by our group (20) and by Druet and cols. (23) is accepted as the "purest" measure of tissue sensitivity to insulin (15). During this procedure, both insulin and glucose levels are clamped, such as under steady-state plasma glucose concentrations, the amount of glucose infused is equal to the amount of glucose metabolized, provided that endogenous hepatic glucose production is suppressed. On the other hand, insulin sensitivity derived from the hyperglycemic clamp depends on endogenous insulin secretion, which may vary tremendously among patients. In addition, calculating insulin sensitivity from the hyperglycemic clamp assumes a linear relationship between plasma insulin concentration and the rate of glucose metabolism. Both these factors may cloud true differences in insulin sensitivity between groups (15). Insulin sensitivity measured by IVGTT with minimal model assessment is another indirect - but relatively - reliable technique in estimating IR. However, the within subject reproducibility of the method in pediatric patients has not be evaluated.

Both Elder and cols. (22) and Kobayashi and cols. (19) used the IVGTT, however the populations they studied were from different ethnic backgrounds: the former being African American and Caucasian and the latter being Japanese. This raises the importance of ethnic/ racial differences in the study of the pathophysiology of T2DM. Genome-wide association studies identified around 20 susceptibility loci robustly implicated in adult T2DM. Some of these loci such as TCF7L2 are frequent in European populations, while others, such as KCNQ1, were identified with higher frequency in East Asian populations (26), suggesting that variations in the genetic background of a population could potentially impact the pathophysiologic risks leading to T2DM (27).

Another important element in assessing insulin sensitivity in youth is body fat topography. It is well established that obesity is associated with IR in all ethnic groups (28). It accounts for $55 \%$ of the variance in in- sulin sensitivity among Caucasians (29), and it was the most important risk factor for IR independent of age, sex or ethnicity in the National Health and Nutrition Examination Survey (NHANES) 1999-2002 data, explaining $29.1 \%$ of the variance in homeostasis assessment model of IR (HOMA-IR) (30).

However, not all obese children develop the same degree of IR. Higher visceral adiposity is associated with $\sim 40 \%$ lower insulin sensitivity in obese children independent of race (31), and with lower levels of adiponectin (32). Waist circumference is an independent predictor of IR (33) and of metabolic syndrome components (34) in obese youth after controlling for BMI percentiles. Moreover, the lipid deposition in the intramyocellular and in the visceral compartments, rather than increased weight per se, are related to the reduction in insulin sensitivity (25). Thus, visceral adiposity is an important risk factor for IR and T2DM development and should be accounted for in studies comparing insulin sensitivity in obese youth with NGT, IGT or T2DM. Not all of the abovementioned studies of insulin sensitivity in youth with T2DM assessed visceral adiposity in the diabetic youth versus the obese controls. Another confounding factor that may be responsible for the divergent findings among the different studies is the varying therapeutic modalities, ranging from lifestyle intervention to insulin sensitizers, to insulin secretagogues, and to insulin in different youths with T2DM.

\section{Insulin secretion in youth T2DM}

In adults, it is widely accepted that defects in beta-cell function are necessary in the pathogenesis of T2DM (17). Studies that evaluated beta-cell function in children with T2DM varied from clear evidence of failure in insulin secretion to relatively preserved beta-cell function (19-24), depending partly on the methodology used and partly on the studied population. Our study demonstrated severe impairment in beta-cell function, $\sim 75 \%$ lower first phase insulin secretion (FPIS), and $\sim 50 \%$ lower second phase insulin secretion (SPIS) in a group of obese adolescents with T2DM of relatively short duration (mean $1.5 \pm 0.5$ years) compared to age, BMI and body fat distribution matched controls (Figure 2B) (20). Similarly, Weiss and cols. reported a decline in FPIS in both adolescents with T2DM and those with IGT that worsened as glucose regulation deteriorated (21). In the same study, a decrease in glucose 
sensitivity of SPIS specific to the T2DM adolescents was found, with no significant differences between the IGT versus NGT obese adolescents (21). Both studies used the hyperglycemic clamp technique, and included control groups with matched body fat composition.

Other studies that used the modified IVGTT technique had somewhat conflicting results. Elder and cols. reported lower first phase insulin response in the T2DM patients versus obese controls; however, the response was similar to that in lean controls. In their study, the control subjects were slightly older than the T2DM patients, and the race distribution was not similar between the three studied groups $(\sim 60 \%$ African Americans in the T2DM group, versus $38 \%$ in the obese controls and only $8 \%$ in the lean controls) (22). Kobayashi and cols. found significantly lower first phase insulin response in young Japanese patients with T2DM compared with lean controls and with obese controls with NGT (19). In a smaller European study of six patients with T2DM (23), first phase insulin response to IVGTT was preserved in three subjects and significantly impaired in the other three. In the same study, insulin secretion in response to a graded intravenous glucose infusion and in response to an arginine test varied from sustained and exaggerated in some patients to impaired in others. The authors attributed this discrepancy in insulin responses to a longer diabetes duration and lack of weight loss in the patients with worse insulin secretion.

All of the aforementioned studies are limited by the relatively small numbers of patients with T2DM (ranging from 6 in the smallest to 22 in the largest), which reflects the relatively low prevalence of T2DM in this age group, despite its increased incidence. However, all of those studies used relatively sensitive methods in assessing beta-cell function, which offsets the power limitation to a certain extent. The hyperglycemic clamp is accepted as the gold standard for assessing beta-cell function in both adults (35) and children (15), and the IVGTT with the minimal model approach is a well validated method for quantification of insulin secretion (36) in adults, but its reproducibility in the pediatric population is unknown - especially when the individual develops hypoglycemia following tolbutamide or insulin injection (15). Moreover, information on insulin secretion alone, without information on insulin sensitivity, does not provide the complete picture. Insulin secretion relative to insulin sensitivity, i.e. the GDI, is the crucial piece of data when assessing beta-cell function. In those studies which evaluated GDI, it was uniformly decreased in young patients with T2DM $(19,20,22,23)$ (Figure 2C).

Defects in proinsulin processing reflected by a high proinsulin to insulin ratio in the T2DM patients compared with IGT and NGT obese controls were reported in some studies $(20,21)$, providing further evidence of impaired beta-cell function. Other studies, however, did not detect any differences in the proinsulin/insulin ratio in either the fasting state or over the first ten minutes after IV glucose infusion between the T2DM patients (22).

Thus, there is convincing evidence that beta-cell failure is an important component in the pathogenesis of T2DM in youth, similar to adults. The severity of reported beta-cell failure in youth T2DM is quite variable and may be influenced by glycemic control (20), duration of diabetes, prior beta-cell function, ethnicity (37) and other yet unknown factors.

In our reported patients, HbAlc correlated inversely with FPIS $(\mathrm{r}=-0.61, \mathrm{p}=0.025)$ and GDI $(\mathrm{r}=-0.77$, $\mathrm{p}=0.004)(20)$. Whether or not this relationship is a reflection of glucotoxicity impacting beta-cell function or poor beta-cell function resulting in elevated $\mathrm{HbAlC}$ can not be deduced from our cross sectional study.

Our data also demonstrated that there are ethnicity related differences in beta-cell function with higher FPIS in black versus white American adolescents with T2DM with comparable HbAlC levels and similar duration of diabetes (37). More research is needed to investigate the factors responsible for variable beta-cell failure in youth with T2DM.

\section{AUTOIMMUNITY AND CLINICALLY DIAGNOSED T2DM IN YOUTH}

Between $10 \%$ to $75 \%$ of youth diagnosed with T2DM based on clinical features, namely obesity, acanthosis nigricans, family history of diabetes, minimal to severe hyperglycemia with or without ketosis, are reported to have beta-cell auto-antibodies (38-43). The antibodies tested and reported to be positive in these patients include ICA, in $5 \%$ to $8 \%(38,40-42)$, GAD in $8 \%$ to $30 \%$ $(38-40,42)$, IA-2 in $8 \%$ to $42 \%(39-42)$, and insulin antibodies in 5 to $35 \%(38-41)$. In one study, $11 \%$ of clinically diagnosed T2DM youth were positive for all four auto-antibodies (40).

These studies, however, had very limited numbers of patients - 15 to 128 participants per reported study, including patients from different racial groups (38-42). Some of these studies investigated - but could not find 
- clinically distinguishing features (obesity, acanthosis nigricans, ketosis, $\mathrm{HbAlC}$ and insulin requirements at diagnosis or on follow-up) between patients with or without beta-cell antibodies $(38,42)$. A preliminary report of a much larger scale of 432 youth with physician diagnosed T2DM screened in the TODAY study revealed that $17.4 \%$ were positive for one or both antibodies, GAD and IA-2 (43). Antibody positive versus negative subjects did not differ in age, diabetes duration, BMI z-score and lipid levels; however, there seemed to be a tendency for C-peptide to be lower and $\mathrm{HbAlC}$ to be higher in antibody positive $\left(\mathrm{Ab}^{+}\right)$youth (43).

Patients who are clinically diagnosed with T2DM but also have evidence of islet cell autoimmunity present a diagnostic challenge, and have been referred to as patients with autoimmune T2DM, hybrid diabetes, diabetes 1.5, double diabetes, and late onset autoimmune diabetes of the young (LADY) (44).

As clinicians caring for such patients, it is crucial to make a proper diagnosis for the appropriate choice of therapy. In a recent study (45), we investigated pathophysiological differences between antibody positive versus antibody negative youth with a clinical diagnosis of T2DM. Using the hyperinsulinemic-euglycemic and the hyperglycemic clamp, we demonstrated important pathophysiologic differences between the two groups. Insulin secretion/beta-cell function was severely impaired in those patients with $\mathrm{Ab}^{+}$compared with those with negative antibodies $\left(\mathrm{Ab}^{-}\right)$(Figure $3 \mathrm{~A}$ ). On the other hand, $\mathrm{Ab}$ patients had severe impairment in insulin sensitivity compared with the $\mathrm{Ab}^{+}$ones and the obese controls, with no difference in insulin sensitivity between obese controls and $\mathrm{Ab}^{+}$patients (Figure 3B) (45). These data imply that obese youth who are clinically diagnosed with T2DM, but have evidence of pancreatic autoimmunity, are, in reality, obese children with type 1 diabetes mellitus (TIDM), without the inherent IR that is typical of patient with T2DM but evidence of autoimmune beta-cell damage manifested in severe insulin deficiency.

Our efforts to find clinically distinguishing characteristics between the two groups did not reveal differences in $\mathrm{HbAlC}$ at diagnosis, BMI and insulin requirements (45). However, ketonuria/ketonemia was significantly more frequent in $\mathrm{Ab}^{+}$versus $\mathrm{Ab}$ patients at initial presentation (45). Furthermore, both blood pressure and ALT were higher in $\mathrm{Ab}$ patients consistent with their underlying severe IR (45). Thus, the Ab group has an inherent IR that is typical of the metabolic syndrome. At the present, it is not clear whether or not the clinical course of $\mathrm{Ab}^{+}$versus $\mathrm{Ab}^{-}$patients would differ, because there are no long-term longitudinal studies assessing the progression of diabetes in either group.

One study assessed insulin requirement of the $\mathrm{Ab}^{+}$ patients one year after diagnosis and did not find significant differences compared with the $\mathrm{Ab}^{-}$ones (42). Previous limited studies from a single group of investigators found that some youth clinically classified with T2DM or indeterminant diabetes (admixture of clinical features of types 1 and 2, T1.5) show T-cell reactivity to islet proteins (40) and have TIDM-associated HLA alleles (41). Baseline C-peptide levels in the T1.5 patients

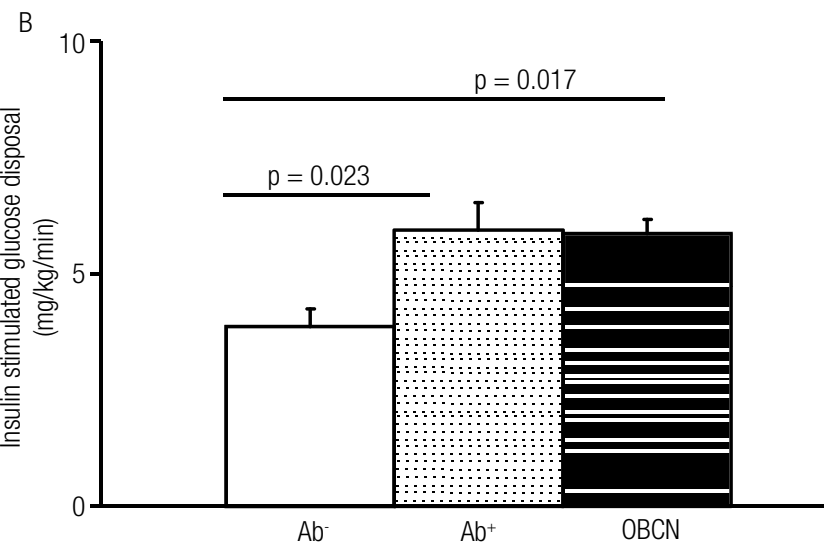

$\mathrm{OBCN}=$ obese children with normal glucose tolerance

Figure 3. (A) First and second phase insulin secretion during the hyperglycemic clamp in $\mathrm{Ab}$ - (empty circles) versus $\mathrm{Ab}^{+}$(filled circles) versus obese controls (filled triangles); (B) insulin stimulated-glucose disposal during the hyperinsulinemic-euglycemic clamp in Ab- (white bars) versus $\mathrm{Ab}^{+}$(dotted bars) versus obese controls (black bars). Adapted with permission from Tfayli and cols. (45). 
were significantly lower than those in patients classified as T2DM and higher than those in patients classified as TIDM (4l). A more aggressive clinical course in patients with autoimmune markers and T2DM phenotype was proposed. The findings in our study are in agreement with this proposition, and provide direct evidence to the more severe degree of impairment in beta-cell function in $\mathrm{Ab}^{+}$patients. The more frequent ketonuria at initial diagnosis in $\mathrm{Ab}+$ patients may be a reflection of the severity of beta-cell impairment. A similar observation of more frequent ketonuria in patients with positive T-cell reactivity or antibodies was made before (40). Additional studies need to be done to pursue the differences between $\mathrm{Ab}^{-}$versus $\mathrm{Ab}^{+}$combined with careful immunological evaluation of T-cell reactivity and HLA antigens.

Our metabolic observations in $\mathrm{Ab}^{+}$versus $\mathrm{Ab}$ youth with T2DM are consistent with findings in GAD positive adults with T2DM or latent autoimmune diabetes (LADA) (46). GAD positive adult patients had decreased early insulin response; however, when the insulin response was corrected for the degree of insulin sensitivity, GAD positive and negative patients had similar beta-cell function. Thus, in the absence of careful metabolic studies using sensitive tools, it will be difficult to discern the underlying pathways, impaired insulin action versus beta-cell function, which may result in similar GDI. However, such knowledge is important to help guide pathopysiology-based therapy amidst the multiple terminologies used, double diabetes, hybrid diabetes, diabetes 1.5 etc.

\section{PROGRESSION FROM NGT TO PREDIABETES, IGT AND T2DM}

Longitudinal studies of adult populations at high risk of developing T2DM, such as the Pima Indians showed that progression from NGT to IGT and to T2DM was associated with an increase in body weight, worsening of insulin sensitivity and a decrease in biphasic insulin secretion $(47,48)$. In the Botnia study, which included 5,396 adults, a progressive decline in insulin sensitivity was observed when moving from NGT to IGT and to diabetes, while an absolute decompensation of betacell function characterized the transition from IGT to T2DM (49).

There are currently no published longitudinal studies pertinent to the progression to overt T2DM in youth. We had the opportunity to follow a high-risk
African American obese female over a five-year period. The progression from NGT to IGT and from IGT to T2DM in this patients was associated with significant weight gain, a large increase in visceral adipose tissue and remarkable decompensation in insulin secretion relative to insulin sensitivity $(50)$. The available pediatric data come mostly from cross sectional studies comparing metabolic differences between NGT, IGT and T2DM - with conflicting findings.

In a recent report by our group, adolescents with T2DM had significantly lower insulin-stimulated total and oxidative glucose disposal compared with IGT and compared with NGT, while no difference was detected between the IGT and the NGT subjects (24) (Figure 4A). An earlier study by Weiss and cols. did not find differences in insulin sensitivity in T2DM adolescents versus those with IGT and those with NGT (21), in contrast to their prior observation of lower insulin sensitivity in adolescents with IGT compared with NGT (25). In the latter study, the adolescents with IGT had significantly higher ratio of visceral to subcutaneous abdominal fat compared to the NGT group, while in the study by Bacha and cols. the three groups had similar percent of body fat and abdominal fat distribution. This could explain the discrepancy in the data, as visceral fat has been associated with lower insulin sensitivity $(25,31)$.

Both T2DM patients and IGT subjects are reported to have significant decrease in first phase insulin responses during the hyperglycemic clamp compared with the NGT subjects $(21,24)$. This decline is more severe in the T2DM patients $\sim 70 \%$ lower, than in the IGT subjects $\sim 40 \%$ lower compared to the NGT subjects (24). This decline was seen in first phase C-peptide secretion during the hyperglycemic clamp as well (24). The second phase insulin response seems to be preserved in the IGT subjects compared to those with NGT $(21,24)$, while it is decreased in the T2DM patients $(21,24)$ by as much as $60 \%$ in one study $(24)$ (Figure 4B). Consistent with these findings, GDI was lowest in T2DM youth compared to those with IGT, and lower in the IGT subjects compared to those with NGT (24) (Figure 4C). In contrast, in a study that screened a multiethnic cohort of obese children using the oral glucose tolerance test (OGTT), youth with IGT had worse OGTT-derived indices of IR compared to those with NGT, while no difference in insulin secretion was detected between the two groups. In the same study, four children with T2DM were identified and had lower insulinogenic index compared to the chil- 

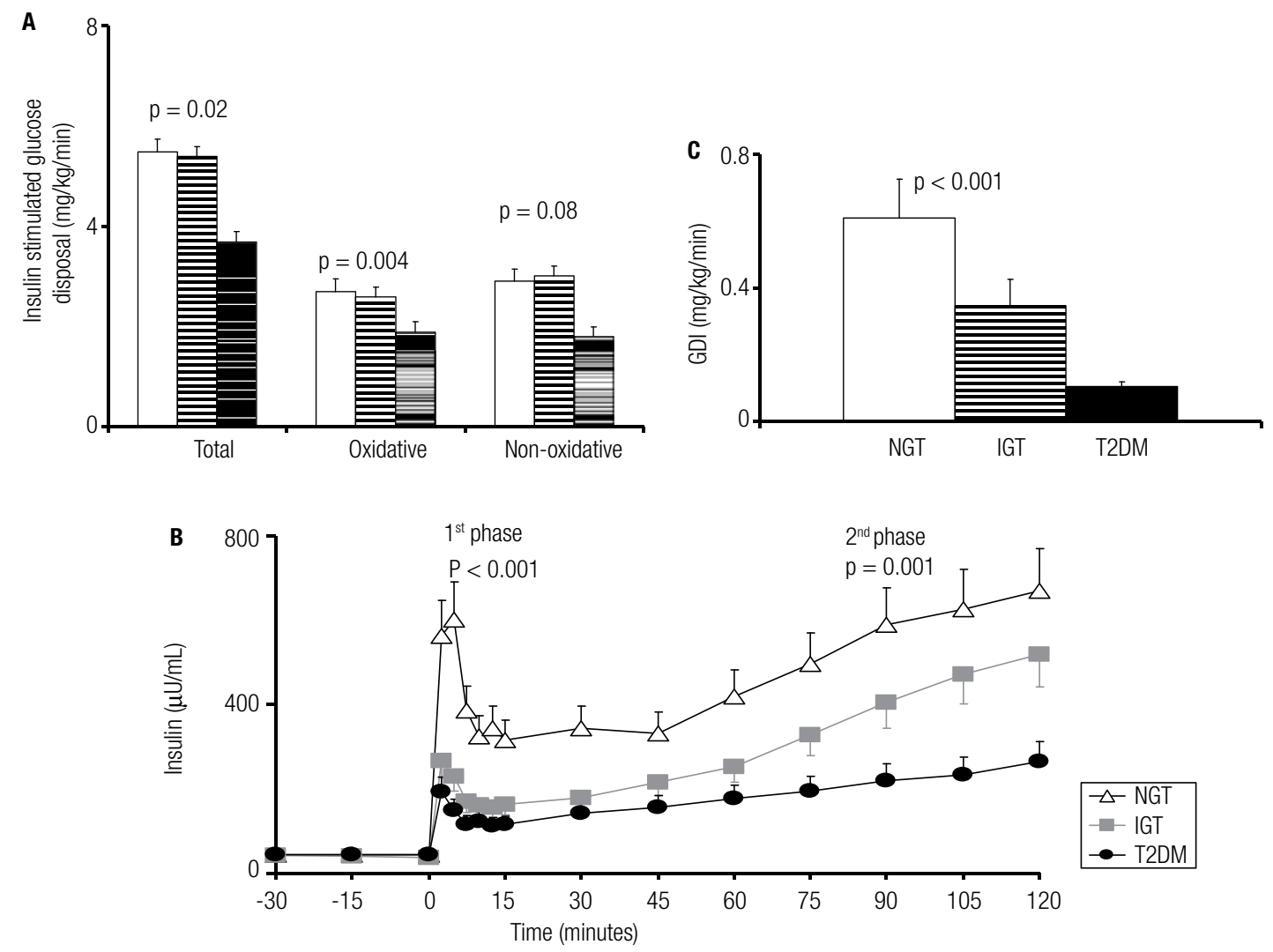

Figure 4. (A) Insulin-stimulated total, oxidative, and nonoxidative glucose disposal in NGT (white bars), IGT (hatched bars) and T2DM (black bars); (B) first and second-phase insulin levels in NGT (open triangles), IGT (hatched squares), and T2DM (filled circles); (C) glucose disposition index in NGT (open bars), IGT (hatched bars) and T2DM (filled bars). Adapted with permission from Bacha and cols. (24).

dren with IGT (51). In overweight Latin children with family history of T2DM, IGT seems to be related to deterioration in beta-cell function (52). Both insulin sensitivity and the GDI in these children are reported to deteriorate over age and to be related to maternal history of T2DM (53).

Thus, based on the available data, it can be postulated that a defect in first phase insulin response is seen early on in the development of T2DM in youth, and defects in second phase response are evident by the time overt diabetes develops. This deterioration occurs in the context of a decline in insulin sensitivity.

\section{FINAL CONSIDERATIONS}

The interplay between insulin sensitivity and insulin secretion determines glucose homeostasis and the progression from normal glucose tolerance to IGT toT2DM in youth. Defects in both insulin action and responses are present in the early stages of T2DM development, and are triggered by environmental modulators against the back drop of genetic susceptibility. Even though the study of T2DM in youth is in its infancy, our knowledge has advanced significantly with more to be learned. As we amass scientific knowledge, T2DM in youth continues to evolve as a chameleon, changing its color every time we think we have come across new information, such as the contrast between $\mathrm{Ab}^{-}$versus $\mathrm{Ab}^{+}$patients. There remains much to be investigated and discovered about youth T2DM, including its future microvascular and macrovascular complications, best therapeutic approaches and potential prevention strategies in these youth afflicted with an adult disease.

Aknowledgments: This work was supported by the United States Public Health Service grant RO1HD27503 (SA), K24 HD01357 (SA), Richard L Day endowed chair (SA) and MOl RR00084 (GCRC) and ULl RR024153 (CTSA), and U01 DK61254 (SA).

Disclosure: No potential conflict of interest relevant to this article was reported.

\section{REFERENCES}

1. Rosenbloom AL, Joe JR, Young RS, Winter WE. Emerging epidemic of type 2 diabetes in youth. Diabetes Care. 1999;22(2:)345-54. 
2. Fagot-Campagna A, Pettitt DJ, Englegau MM, Burrows NR, Geiss LS, Valdez R, et al. Type 2 diabetes among North American children and adolescents: an epidemiologic review and a public health perspective. J Pediatr. 2000;136(5):664-72.

3. Pinhas-Hamiel O, Zeitler P. The global spread of type 2 diabetes mellitus in children and adolescents. J Pediatr. 2005;146(5):693-700.

4. Rosenbloom AL, Silverstein JH, Amemiya S, Zeitler P, Klingensmith GJ. ISPAD Clinical Practice Consensus Guidelines 20062007. Type 2 diabetes mellitus in the child and adolescent. Pediatric Diabetes. 2008;9(2):512-26.

5. Writing Group for the SEARCH for Diabetes in Youth Study Group, Dabelea D, Bell RA, D'Agostino RB Jr, Imperatore G, Johansen JM, Linder B, Liu LL, Loots B, Marcovina S, Mayer-Davis EJ, Pettitt DJ, Waitzfelder B. Incidence of diabetes in youth in the United States. JAMA. 2007; 297(24):2716-24.

6. Rotteveel J, Belksma EJ, Renders CM, Hirasing RA, Delemarre-Van deWaal HA.Type 2 diabetes in children in the Netherlands: the need for diagnostic protocols. Eur J Endocrinol. 2007;157(2):175-80.

7. Feltbower RG, McKinney PA, Campbell FM, Stephenson $C R$, Bodansky HJ. Type 2 and other forms of diabetes in 0-30 year olds: a hospital based study in Leeds, UK. Arch Dis Child. 2003;88(8):676-9.

8. Ortega-Rodriguez E, Levy-Marchal C, Tubiana N, Czernichow P, Polak M. Emergence of type 2 diabetes in an hospital based cohort of children with diabetes mellitus. Diabetes Metab. 2001;27(5 Pt 1):574-8.

9. Wei JN, Sung FC, Lin CC, Lin RS, Chiang CC, Chuang LM. National surveillance for type 2 diabetes mellitus in Taiwanese children. JAMA. 2003;290(10):1345-50.

10. Urakami T, Morimoto S, Nitadori Y, Harada K, Owada M, KitagawaT. Urine glucose screening program at schools in Japan to detect children with diabetes and its outcome-incidence and clinical characteristics of childhood type 2 diabetes in Japan. Pediatr Res. 2007;61(2):141-5.

11. Moussa MA, Alsaeid M, Abdella N, RefaiTM, Al-Sheikh N, Gomez JE. Prevalence of type 2 diabetes mellitus among Kuwaiti children and adolescents. Med Princ Pract. 2008;17(4):270-5.

12. Dabelea D, Pettitt DJ, Jones KL, Arslanian SA. Type 2 diabetes mellitus in minority children and adolescents. An emerging problem. Endocrinol Metab Clin North Am. 1999;28(4):709-29.

13. Bacha $\mathrm{F}$, Arslanian $\mathrm{S}$. Insulin resistance and insulin secretion in the pathophysiology of youth type 2 diabetes. In: Dabelea D, Klingensmith $\mathrm{G}$, editors. Epidemiology of pediatric and adolescent diabetes. First edition. New York: Informa Healthcare; 2008. p.139-64.

14. Kahn SE. The relative contributions of insulin resistance and beta-cell dysfunction to the pathophysiology of Type 2 diabetes. Diabetologia. 2003;46(1):3-19.

15. Arslanian SA. Clamp techniques in paediatrics: what have we learned? Horm Res. 2005;64 Suppl 3:16-24.

16. Bergman RN, Ader M, Huecking K, Van Citters G. Accurate assessment of $\beta$-cell function: the hyperbolic correction. Diabetes. 2002; 51(Suppl. 1):S212-20.

17. Kahn SE. The relative contributions of insulin resistance and beta-cell dysfunction to the pathophysiology of type 2 diabetes. Diabetologia. 2003;46(1):3-19.

18. Gungor N, Hannon T, Libman I, Bacha F, Arslanian S. Type 2 diabetes mellitus in youth: the complete picture to date. Pediatr Clin North Am. 2005;52(6):1579-609.

19. Kobayashi K, Amemiya S, Higashida K, Ishihara T, Sawanobori E, Kobayashi $K$, et al. Pathogenic factors of glucose intolerance in obese Japanese adolescents with type 2 diabetes. Metabolism. 2000;49(2):186-91.
20. Gungor N, Bacha F, Saad R, Janosky J, Arslanian S. Youth type 2 diabetes: insulin resistance, beta-cell failure, or both? Diabetes Care 2005;28(3):638-44.

21. Weiss R, Caprio S, Trombetta M, Taksali WV, Bonadonna R. Betacell function across the spectrum of glucose tolerance in obese youth. Diabetes. 2005;54(6):1735-43.

22. Elder DA, Prigeon RL, Wadwa RP, Dolan LM, D'Alessio DA. Betacell function, insulin sensitivity, and glucose tolerance in obese diabetic and nondiabetic adolescents and young adults. J Clin Endocrinol Metab. 2006;91(1):185-91.

23. Druet C, Tubiana-Rufi N, Chevenne D, Rigal O, Polak M, LevyMarchal C. Characterization of insulin secretion and resistance in type 2 diabetes of adolescents $\mathrm{J}$ Clin Endocrinol Metab. 2006;91(2):401-4.

24. Bacha F, Gungor N, Lee S, Arslanian SA. In vivo insulin sensitivity and secretion in obese youth: what are the differences between normal glucose tolerance, impaired glucose tolerance, and type 2 diabetes? Diabetes Care. 2009; 32(1):100-5.

25. Weiss R, Dufour S, Taksali SE, Tamborlane WV, Petersen KF, Bonadonna RC, et al. Prediabetes in obese youth: a syndrome of impaired glucose tolerance, severe insulin resistance, and altered myocellular and abdominal fat partitioning. Lancet. 2003;362(9388):951-7.

26. McCarthy MI. Casting a wider net for diabetes susceptibility genes. Nat Genet. 2008;40(9):1039-40.

27. FraylingTM. Genome-wide association studies provide new insights into type 2 diabetes aetiology. Nat Rev Genet. 2007;8(9):657-62.

28. Crossrow N, Falkner B. Race/ethnic issues in obesity and obesity-related comorbidities. J Clin Endocrinol Metab. 2004;89(6):2590-4.

29. Arslanian SA, Suprasongsin C. Insulin sensitivity, lipids, and

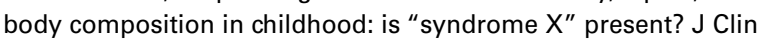
Endocrinol Metab. 1996;81(3):1058-62.

30. Lee JM, Okumura MJ, Davis MM, Herman WH, Gurney JG. Prevalence and determinants of insulin resistance among US adolescents. Diabetes Care. 2006;29(11):2427-32.

31. Bacha F, Saad R, Gungor N, Janosky J, Arslanian SA. Obesity, regional fat distribution and syndrome $X$ in obese black vs white adolescents: race differential in diabetogenic and atherogenic risk factors. J Clin Endocrinol Metab. 2003;88(6):2534-40.

32. Bacha F, Saad R, Gungor N, Arslanian S. Adiponectin in youth: relationship to visceral adiposity, insulin-sensitivity, and beta-cell function. Diabetes Care. 2004;27(2):547-52.

33. Lee S, Bacha F, Gungor N, Arslanian S. Waist circumference is an independent predictor of insulin resistance in African-American and White youth. J Pediatr. 2006;148(2):188-94.

34. Lee S, Bacha F, Arslanian S. Waist circumference, blood pressure and lipid components of the metabolic syndrome. J Pediatr. 2006;149(6):809-16.

35. De Fronzo RA, Tobin JD, Andres R. Glucose clamp technique: a method for quantifying insulin secretion and resistance. Am J Physiol. 1979;237(3):E214-23.

36. Bergman RN. Lilly lecture 1989. Toward physiological understanding of glucose tolerance: Minimal-model approach. Diabetes. 1989; 38(12):1512-27

37. Bacha F, Gungor N, Lee S, Arslanian S. Pathophysiology of type 2 diabetes in youth: are rhere racial differences? Diabetes. 57;(Suppl. 1):A857.

38. Hathout EH, Thomas W, El-Shahawy M, Nahab F, Mace JW. Diabetic autoimmune markers in children and adolescents with type 2 diabetes. Pediatrics. 2001;107(6):E102.

39. Umpaichitra V, Banerji MA, Castells S. Autoantibodies in children with type 2 diabetes mellitus. J Pediatr Endocrinol Metab. 2002;15 Suppl. 1:525-30. 
40. Brooks-Worrell BM, Greenbaum CJ, Palmer JP, Pihoker C. Autoimmunity to islet proteins in children diagnosed with new-onset diabetes. J Clin Endocrinol Metab. 2004; 89(5):2222-7.

41. Gilliam L, Brooks-Worrell B, Palmer J, Greenbaum C, Pihoker C. Autoimmunity and clinical course in children with type 1, type 2, and type 1.5 diabetes. J Autoimmunity. 2005;25(3):244-50.

42. Reinehr T, Schober E, Wiegand S, Thon A, Holl R; DPV-Wiss Study Group: Beta-cell autoantibodies in children with type 2 diabetes mellitus: subgroup or misclassification? Arch Dis Child. 2006;91(6):473-7.

43. Klinkgensmith GJ, Coombs LP, Arslanian S, Copeland K, Cuttler L, Haffner S, Kaufman F, Laffel L, Linder B, Marcovina SM, Tollefsen SE, Weinstock RS; for the TODAY study group. Autoantibody positivity in subjects screened for participation in a treatment trial forT2D in youth. Diabetes. 2006;55(Suppl. 1): 67.

44. Pozzilli P, Guglielmi C, Pronina E, Petraikina E. Double or hybrid diabetes associated with an increase in type 1 and type 2 diabetes in children and youths. Pediatr Diabetes. 2007;8 Suppl. 9:88-95.

45. Tfayli H, Bacha F, Gungor N, Arslanian A. Phenotypic type 2 diabetes in obese youth: insulin sensitivity and secretion in isletcell antibody negative vs. antibody positive patients. Diabetes 2009:58:738-44.

46. Zinman B, Kahn SE, Haffner SM, O'Neill MC, Heise MA, Freed MI; ADOPT Study Group. Phenotypic characteristics of GAD antibody-positive recently diagnosed patients with type 2 diabetes in North America and Europe. Diabetes. 2004;53(12):3193-200.
47. Weyer C, Bogardus C, Mott DM, Pratley RE. The natural history of insulin secretory dysfunction and insulin resistance in the pathogenesis of type 2 diabetes mellitus. J Clin Invest. 1999; 104(6):787-94.

48. Festa A, Williams K, D'Agostino R Jr, Wagenknecht LE, Haffner SM. The natural course of beta-cell function in nondiabetic and diabetic individuals: the Insulin Resistance Atherosclerosis Study. Diabetes. 2006;55(4):1114-20.

49. Tripathy $D$, Carlsson $M$, Almgren $P$, Isomaa B, Taskinen MR, Tuomi T, et al. Insulin secretion and insulin sensitivity in relation to glucose tolerance: lessons from the Botnia Study. Diabetes. 2000;49(6):975-80.

50. Saad R, Gungor N, Arslanian S. Progression from normal glucose tolerance to type 2 diabetes in a young girl: longitudinal changes in insulin sensitivity and secretion assessed by the clamp technique and surrogate estimates. Pediatr Diabetes. 2005;6(2):95-9.

51. Sinha R, Fisch G, Teague B, Tamborlane WV, Banyas B, Allen K, et al. Prevalence of impaired glucose tolerance among children and adolescents with marked obesity. N Engl J Med. 2002;346(11):802-10.

52. Goran MI, Bergman RN, Avila Q, Watkins M, Ball GD, Shaibi GQ, et al. Impaired glucose tolerance and reduced beta-cell function in overweight Latino children with a positive family history for type 2 diabetes. J Clin Endocrinol Metab. 2004;89(1):207-12.

53. Kelly LA, Lane CJ, Weigensberg MJ, Koebnick C, Roberts CK, Davis $\mathrm{JN}$, et al. Parental history and risk of type 2 diabetes in overweight Latino adolescents: a longitudinal analysis. Diabetes Care. 2007;30(10):2700-5 